\title{
Inhibition of Microbial Multiplication by Hypocholesteraemic Compounds
}

\author{
BY S. AARONSON \\ Haskins Laboratories, New York, N.Y. 10017, and Biology Department, \\ Queens College, City University of New York, Flushing, N.Y. 11367, U.S.A. \\ SUMMARY \\ The hypocholesteraemic compounds benzmalecene and triparanol in- \\ hibited multiplication of certain bacteria (especially Gram-positive organ- \\ isms), protozoa, algae and ascomycetes but not other higher fungi. Oleic \\ acid (or methyl oleate) annulled the inhibition in bacteria, algae, protozoa \\ and a yeast.
}

\section{INTRODUCTION}

Certain hypocholesteraemic compounds, e.g. benzmalecene and triparanol, which interfere with sterol synthesis in mammals (Holmes \& Di Tullio, 1962) have been observed to inhibit protozoan multiplication (Aaronson, Bensky, Shifrine \& Baker, 1962) and respiration (Aaronson, 1964a), and Rhodopseudomonas palustris multiplication (Aaronson, 1964b). The inhibitions of microbial multiplication were annulled best by unsaturated fatty acids; sterols and sterol precursors were less effective or were ineffective. Presumably the hypocholesteraemic compounds interfere with unsaturated fatty acid metabolism in the micro-organisms, rather than with sterol metabolism as in mammals.

\section{METHODS}

Micro-organisms from the collection of Haskins Laboratories and the Biology Department, Queens College, New York, were used. For disc assays, filter-paper discs $(\mathbf{1 2 . 7} \mathrm{mm}$. diam.) were soaked in solutions of the test compound, dried and autoclaved. Various agar media appropriate for the growth of the micro-organisms, e.g. nutrient agar for the bacteria, and Sabouraud's glucose agar for the fungi, were seeded with test micro-organisms. Cultures were incubated at $25^{\circ}$ for $5-10$ days. In some experiments chemically defined liquid media were used appropriate to the protozoan or alga. Benzmalecene (BM; N-[1-methyl-2,3-di-( $p$-chlorophenyl)propyl]maleamic acid) was supplied by Dr D. Hendlin (Merck, Sharp and Dohme Laboratories, Rahway, N.J.). Triparanol (TR; 1- $[p$-( $\beta$-diethylaminoethoxy)phenyl]-1-( $p$-tolyl)-2- $p$-chlorophenyl ethanol) was supplied by Dr F. J. Murray (W. S. Merrell, Cincinnati, Ohio). Benzmalecene was dissolved in dilute alkali, and triparanol in $95 \%(\mathrm{v} / \mathrm{v})$ ethanol in water. Oleic acid $(99 \%$ pure by gas-liquid chromatography) was bought from the Hormel Institute, Austin, Minnesota. The other chemicals were of a commercial grade. 
Table 1. Inhibition of micro-organisms by hypocholesteraemic compounds

Key:

1 Bacteria showed zone of inhibition around dises soaked in $0.1 \%$ or $1.0 \%(w / v)$ concentration of inhibitor.

* Inhibited on nutrient agar plates but not in defined liquid medium.

+ Inhibited on nutrient agar plates and in defined liquid medium.

Results of M. Shifrine.

$\S$ Results of G. G. Holz, Jr.

\begin{tabular}{|c|c|c|c|c|c|}
\hline Schizomycetes & $\begin{array}{l}\text { Benz- } \\
\text { malecene }\end{array}$ & $\begin{array}{l}\text { Tri- } \\
\text { paranol }^{1}\end{array}$ & & $\begin{array}{c}\text { Benz- } \\
\text { malecene }{ }^{1}\end{array}$ & $\begin{array}{c}\text { Tri- } \\
\text { paranol }^{1}\end{array}$ \\
\hline \multicolumn{3}{|l|}{ Gram-positive } & \multicolumn{3}{|l|}{ Ascomycetes } \\
\hline Bacillus cereus & + & + & Dipodascus uninucleatus & - & $+t$ \\
\hline B. megatherium & + & + & Endomycopsis javanensis & - & $+\ddagger$ \\
\hline B. mesentericus & + & + & Lipomyces starkey & - & $+\ddagger$ \\
\hline B. mycoides & + & + & Penicillium chrysogenum & - & $+\$$ \\
\hline Brevibacterium linens & + & + & Pichia fermentans & - & $+\ddagger$ \\
\hline Corynebacterium linens & + & + & Rhodotorula marina & - & $+\dot{t}$ \\
\hline C. pointsettiae & + & + & Saccharomyces cerevisiae & + & + \\
\hline C. pseudodiphtheriticum & + & + & S. rosei & . & $+\ddagger$ \\
\hline C. xerosus & + & + & Saccharomycopsis guttulata & . & ++ \\
\hline C. bovis & + & + & Schizosaccharomyces pombe & . & + \\
\hline Lactobacillus casei & - & - & Sordaria sp. & + & + \\
\hline L. plantarum & . & +8 & Torulopsis utilis & - & $+\S$ \\
\hline Micrococcus luteus & + & + & \multirow{2}{*}{\multicolumn{3}{|c|}{ Phycomycetes }} \\
\hline M. lysodeikticus & + & + & & & \\
\hline$M$. roseus & + & + & Phycomyces sp. & - & - \\
\hline M. sodonensis & + & + & Rhizopus nigricans & - & - \\
\hline Sarcina flava & + & + & \multirow{2}{*}{\multicolumn{3}{|c|}{ Basidomycetes }} \\
\hline S. lutea & + & + & & & \\
\hline Staphylococcus albus & + & + & Sporobolomyces sp. & $\cdot$ & $-\ddagger$ \\
\hline S. aureus & + & + & \multicolumn{3}{|l|}{ Algae } \\
\hline $\begin{array}{l}\text { S. citreus } \\
\text { Mycobacterium lacticola }\end{array}$ & $\begin{array}{l}+ \\
+\end{array}$ & $\begin{array}{l}+ \\
+\end{array}$ & \multirow{2}{*}{$\begin{array}{l}\text { Coccochloris elabens } \\
\text { (Cyanophyta) } \\
\text { Chlorella pyrenoidosa } \\
\text { (Chlorophyta) }\end{array}$} & + & + \\
\hline $\begin{array}{l}\text { M. smegmatis } \\
\text { M. phlei }\end{array}$ & $\begin{array}{l}+ \\
.\end{array}$ & $\begin{array}{l}+ \\
+8\end{array}$ & & - & $+\S$ \\
\hline Gram-negative & & & \multicolumn{3}{|l|}{ Protozoa } \\
\hline Aerobacter aerogenes & $-*$ & $-*$ & \multirow{11}{*}{$\begin{array}{l}\text { Euglena gracilis } \\
\text { Ochromonas danica } \\
\text { Tetrahymena pyriformis } \\
\text { T. corlissi }\end{array}$} & \multirow{11}{*}{$\begin{array}{l}+ \\
+ \\
+ \\
.\end{array}$} & \multirow{11}{*}{$\begin{array}{l}+ \\
+ \\
+ \\
+\$\end{array}$} \\
\hline Agrobacterium tumefaciens & · & +8 & & & \\
\hline Escherichia coli & $-\dagger$ & $-\dagger$ & & & \\
\hline Klebsiella pneumoniae & - & - & & & \\
\hline Paracolobactrum intermedium & - & - & & & \\
\hline Proteus mirabilis & - & - & & & \\
\hline P. vulgaris & - & - & & & \\
\hline Pseudomonas aeruginosa & - & - & & & \\
\hline Salmonella gallinarum & - & - & & & \\
\hline Serratia marcescens & - & - & & & \\
\hline Rhodopseudomonas palustris & + & + & & & \\
\hline
\end{tabular}

\section{RESULTS}

Almost all the Gram-positive bacteria and almost none of the Gram-negative bacteria tested were inhibited by BM and TR (Table 1). Multiplication of several algae, protozoa and ascomycetes but not phycomycetes or a basidiomycete was also inhibited (Table 1). The Gram-positive mycobacteria were most sensitive to BM and TR by plate assay (Table 2 ).

Inhibition by BM and TR of the multiplication of a bacterium Corynebacterium bovis, a blue-green alga Coccochloris elabens, and a yeast Saccharomyces cerevisiae, 
$0.3 \%$ in Gram-positive bacteria and $11-22 \%$ in Gram-negative (Salton, 1960). The sensitivity of the ascomycetes and the insensitivity of the other fungi tested draw attention to the mounting evidence for deep-seated differences between the ascomycetes and eumycophyta. Bergh, Webb \& McArthur (1964) suggested that the Gram reaction may be associated with the resistance of the lipids of Gram-positive organisms to extraction by polar solvents. Ascomycetes are Gram-positive and like the Gram-positive bacteria were inhibited by benzmalecene and triparanol, both compounds known to affect lipid metabolism in animals. The annulment of BM and TR inhibition of microbial multiplication by oleic acid, rather than by saturated fatty acids, sterols or sterol precursors, suggests that lipid metabolism in the microorganisms tested differs from lipid metabolism in mammals. In mammals BM and TR inhibit primarily sterol synthesis (Holmes \& Di Tullio, 1962) and fatty acid synthesis is only secondarily affected (Garattini et al. 1961). The hypocholesteraemic compound triparanol has a low toxicity for humans even in high concentrations (Furman \& Robinson, 1961) although side-effects have been noted (Steinberg, 1962; Achor, Christensen, Berge \& Mason, 1963; Roe, 1964). The sensitivity of the Grampositive bacteria tested, notably the Mycobacterium species, to triparanol and benzmalecene may prove useful in the design of a new group of chemotherapeutic agents.

Aided by grants B-02651 and GM-09103 from the U.S. National Institutes of Health. I am grateful to Dr M. Shifrine (Department of Avian Medicine, University of California, Davis, California) and Dr G. G. Holz, Jr. (Microbiology Department, Medical School, Syracuse University, Syracuse, N.Y.) for the use of their unpublished data.

\section{REFERENCES}

Aaronson, S. (1964a). Inhibition of respiration in a flagellate protozoon by hypocholesterolemic drugs. Nature, Lond. 202, 1355.

Aaronson, S. (1964b). A role for a sterol and a sterol precursor in the bacterium Rhodopseudomonas palustris. J. gen. Microbiol. 37, 225.

Aaronson, S., Bensky, B., Shifrine, M. \& Baker, H. (1962). Effect of hypocholesteremic agents on protozoa. Proc. Soc. exp. Biol., Med. 109, 130.

Achor, R. W. P., Christensen, N. A., Berge, K. G. \& Mason, H. L. (1963). Treatment of hypercholesteremia with triparanol and comparison with nicotinic acid. Proc. Staff Meetings Mayo Clin. 38, 32.

Bergh, A. K., Webi, S. J. \& McArthur, C. S. (1964). Bacterial lipids and the Gram staining reaction. Canad. J. Biochem. 42, 1141.

Furman, R. H. \& Robinson, Jr., C. W. (1961). Hypocholesterolemic agents. Med. Clin. N. Amer. 45, 935.

Garattini, S., Paoletti, R., Bizzi, L., Grossi, E. \& Vertua, R. (1961). A comparative evaluation of hypocholesteremizing drugs on several tests. Drugs affecting Lipid Metabolism, pp. 144-157. Ed. by S. Garattini \& R. Paoletti. Amsterdam: Elsevier Publishing Co.

Holmes, W. L. \& Di Tuluio, N. W. (1962). Inhibitors of cholesterol biosynthesis which act at or beyond the mevalonic acid stage. Amer. J. clin. Nutrition, 10, 310.

Roz, D. A. (1964). Cutaneous effects of hypocholesteremic agents. N.Y. St. J. Med. 64, 2559.

SALton, M. R. J. (1960). Surface layers of the bacterial cell. The Bacteria, Vol. 1, pp. 97-151. Ed. by I. C. Gunsalus \& R. Y. Stanier. New York: Academic Press Inc.

Steinberg, D. (1962). Chemotherapeutic control of serum lipid levels. Trans. N.Y. Acad. Sci. 24, 704. 
Note added in proof

Since writing this paper, the author's attention has been drawn to Smith, R.F., Shay, D. E. and Doorenbas, N. J. (1963) 'Antimicrobiol action of nitrogen-containing steroids' J. Bact. 85, 1295, who state that nitrogen-containing steroids, compounds resembling certain hypocholesteremic compounds i.e. azacholestanol, inhibited the multiplication of certain yeasts, moulds, actinomycetes, and Gram-positive bacteria but not most Gram-negative bacteria tested. 